\title{
Melanoma Ganglionic Metastasis 30 years after treatment of the primary tumor - A case report
}

Head and Neck Surgery Services of the Department of Surgery at the School for Medical Science at the State University of Campinas (UNICAMP) - Campinas, Brazil

The recurrence of melanoma in patients is well-documented, and is dependent on a number of factors. We report a case in which a patient had a case of ganglionar metastasis in the neck after a 30-year disease-free interval following primary treatment.

UNITERMS: Late metastasis of cutaneous melanoma. Cutaneous melanoma. Head and neck melanoma.

\section{INTRODUCTION}

$\mathrm{T}$ The recurrence of melanoma is a well-documented clinical fact in the medical literature. ${ }^{3}$ At the Head and Neck Surgery Services of the Department of Surgery at UNICAMP, we had a case in which a patient showed cervical lymphatic metastasis 30 years after being diagnosed and treated for a primary lesion situated on the skin in the suprascapular region.

\section{CASE REPORT}

In 1963, M.R.V., an 18-year old woman, displayed a dark nodular lesion $1.0 \mathrm{~cm}$ in diameter on the skin in the

\section{Address for correspondence:}

Alfio José Tincani

Rua Luverci Pereira de Souza, 1765

Campinas/SP - Brasil - CEP 13084-031 right suprascapular region. She was treated at another clinic. An ample resection of the lesion was performed and an anatomopathological histological test revealed it to be a Clark III and Breslow $1.2 \mathrm{~mm}$ melanoma. The patient was followed for six consecutive years without evidence of local recurrence or metastasis.

In 1993, at the age of 48 , the patient contacted us on account of the appearance of a hardened nodule in the right supraclavicular fossae. The tumor appeared in the area of drainage of the previous nodule.

Laboratory exams and imaging were completed not only to determine the patient's stage, but also to exclude a second primary tumor. The diagnosis of metastasis of the melanoma was confirmed by an aspirate of the cervical ganglion with a fine needle. In May of 1993, a cervical ganglionic removal of the upper, mid, and lower jugular carotid chain was performed on the patient, as well as on the supraclavicular fossae on the right side (levels II, III, IV and V). The final histological examination revealed metastasis melanoma with extracapsular invasion in 1 cervical lymph node among 21 examined. The patient has been in ambulatory follow-up for 15 months without evidence of disease. 


\section{DISCUSSION}

The majority of recurrences and deaths from cutaneous melanoma occur within the first 10 years of diagnosis and treatment of the primary lesion, and are common after this period. ${ }^{3.6}$

In the medical literature, ${ }^{7}$ there has only been one description of late recurrence with a disease-free interval of 30 years, as in the case of our patient. The majority of recurrences described occurred between 10 and 20 years later. ${ }^{1,23.6 .7}$ The slight possibility of a recurrence after 30 years leads us to consider that this may be the case of a second primary tumor. ${ }^{2}$ Most late recurrences involving lymph nodes occur in the area of the drainage of the primary tumor. However, SHAW et al.$^{6}$ describe 47 percent of their cases of late recurrences in areas distant from the primary lesion (distant lymph nodes, subcutaneous nodules or visceral metastasis or in the central nervous system).

A review of the cases described in the literature reveal common characteristics in the patients with cutaneous melanoma with late recurrences. The majority of patients are premenopausal women under the age of 50, which suggests that natural steroid tumors may affect the natural history of the patients. 'Also, occurrence in the lower limbs is more common in women, and has a more favorable prognosis. ${ }^{1.6}$

$\mathrm{KOH}$ et $\mathrm{al}^{3}{ }^{3}$ describe two cases of recurrences of melanoma 14 and 18 years after treatment of the primary tumor. A possible explanation for this phenomenon of late recurrence could be that a small portion of tumor cells could have a potential for metastasis, and in individuals with a subsequent recurrence, these cells could have been dormant for years before becoming evident.

MASTRANGELO et al. ${ }^{4}$ believe that there is a connection to the immune system of the host. There could be a loss of antingenic manifestation altering the tumor immunogenicity or of the immune system of the host, therefore causing the late metastasis.

REINTGAN et al..$^{5}$ believe that immunological factors could also cause a second primary metacronic tumor, and this would recede spontaneously leaving only the metastatic disease. This can be observed in 5 percent of the cases of metastatic melanoma.

\section{CONCLUSION}

The occurrence after an interval of 30 years between treatment of the primary tumor and the appearance of a ganglioma metastasis is extremely rare in all malignant tumors, especially in the case of cutaneous melanoma. Only from 1 to 7 percent of the patients treated for cutaneous melanoma develop a recurrence 10 years after the initial treatment. Premenopausal women with a melanoma located in the lower limbs have a greater chance of late recurrence.

A follow-up of the patient over a long period (more than 10 years) is essential for identification and early treatment of recurrences.

\section{RESUMO}

A recidiva de melanoma em pacientes previamente tratados é bastante descrito na literatura e esta recidiva depende de vários fatores. Apresentamos um caso de melanoma cutâneo metastático para região cervical onde a paciente teve um intervalo livre da doença de 30 anos entre seu tratamento inicial e o aparecimento da metástase ganglionar. 


\section{REFERENCES}

1. Briele HA, Beattie CW, Ronan SG, Chaudhuri PK, Das Gupta TK. Late recurrence of cutaneous melanoma. Arch Surg 1983;118:800-3.

2. Callaway MP, Briggs JC. The incidence of late recurrence (greater than ten years): An analysis of 536 consecutive cases of cutaneous melanoma. Br J Plast Surg 1989;42:46-9.

3. Koh HK, Sober AJ, Fitzpatrick TB. Late recurrence (beyond ten years) of cutaneous malignant melanoma. JAMA 1984;251:1859-62.
4. Mastrangelo MJ, Bellet RE, Berd D. Immunology and Immunotherapy on human cutaneous malignant melanoma. In: Clark WH, Goladman LI, Matrangleo MJ, eds. Human Maligant Melanoma. New York:Grune \& Stratton Inc., 1979:355-416.

5. Reintgen DS, McCarty KS, Woodard B. Metastatic malignant melanoma with unknown primary. Surg Gynecol Obstet 1982;156:335-40.

6. Shaw HM, Beattie CW, McCarthy WH, Milton GW. Late relapse from cutaneous Stage I malignant melanoma. Arch Surg 1985;120:1155-9.

7. Tahery DP, Moy RL. Recurrent Malignant Melanoma following a 35-year disease-free interval. Int J Derml Surg Oncol 1993;19:161-3. 